\title{
ФИЗИОЛОГИЧЕСКИЕ И ГЕНЕТИЧЕСКИЕ МЕХАНИЗМЫ ОТВЕТА ЧАЙНОГО РАСТЕНИЯ Camellia sinensis (L.) Kuntze НА ЗАСУХУ
} (обзор)

\section{Л.С. САМАРИНА, А.В. РЫНДИН, Л.С. МАЛЮКОВА, М.В. ГВАСАЛИЯ, В.И. МАЛЯРОВСКАЯ}

Основной лимитирующий фактор выращивания чайного растения - засуха. Она снижает продуктивность плантаций на 15-45 \% (R.M. Bhagat с coaвT., 2010; R.D. Baruah c coaвT., 2012) и может приводить к гибели растений (Е.К. Cheruiyot с соавт., 2009). Этим обусловлен интерес исследователей к физиолого-биохимическим (М. Mukhopadhyay с соавт., 2014; Т.K. Maritim с соавт., 2015) и молекулярным (W.D. Wang с соавт., 2016; Y. Guo с соавт., 2017) механизмам устойчивости растений чая к засухе. Целью настоящего обзора стало обобщение международного опыта фенотипирования и генотипирования чайного растения по признаку устойчивости к стресс-фактору для составления целостной картины реакции растения на осмотический стресс и понимания воспроизводимости механизмов ответа в разных климатических зонах. Основную сигнальную роль в этих процессах играют абсцизовая, жасмоновая и салициловая кислоты, а также этилен (S.C. Liu с соавт., 2016), метаболический путь которых включает каскады физиологических реакций и генов ответа (T. Umezawa с соавт., 2010). В период засухи у чайного растения повышается экспрессия генов, кодирующих ферменты биосинтеза цитокининов (трансзеатин и цис-зеатин и изопентиниладенин), а при восстановлении растений после стресса экспрессия снижается. Предполагается, что повышение содержания цитокининов может частично смягчать негативное влияние стресса на фотосинтетическую активность и замедлять ускоренное старение листьев. К важным адаптивным реакциям растений на этот стресс относится повышение концентрации пролина, глицин-бетаина, маннита и других осмолитов, которые нейтрализуют активные формы кислорода, защищают макромолекулы от повреждения свободными радикалами и поддерживают осмотический потенциал клетки (W.D. Wang с соавт., 2016). В условиях засухи у чая происходит расщепление крахмала до глюкозы, повышение синтеза маннита, трегалозы, сахарозы. Накопление активных форм кислорода напрямую коррелирует с аккумуляцией глюкозы. Показано, что в формирование устойчивости к осмотическому стрессу вовлечено множество генов, участвующих в метаболизме и сигналинге фитогормонов, осмолитов, антиоксидантов и углеводов (S. Gupta с соавт., 2013; Y. Guo с соавт., 2017). Проанализировано несколько семейств транскрипционных факторов, которые участвуют в регуляции ответа на засуху у чая. B семействе bHLH обнаружено 39 генов CsbHLH, экспрессия которых повышалась в условиях засухи (Х. Cui с соавт., 2018). Гены $C s N A C 17$ и $C s N A C 30$ из семейства NAC могут быть использованы в селекции на засухоустойчивость чая (Y.-X. Wang с соавт., 2016). Ген CsWRKY2 из семейства WRKY действует как активатор или репрессор абсцизовой кислоты (АБК). В семействе генов DREB известно $29 \mathrm{CS} D R E B$, которые повышают устойчивость чая к засухе через АБК-зависимый и АБК-независимый путь (M. Wang с соавт., 2017). Из семейства HD-Zip у чая выявлены гены Cshdz, которые по функциям разделяются на четыре группы; наибольшую роль в ответе на засуху играют HD-Zip I и HD-Zip IV (W. Shen с соавт., 2018). Из семейства HSP (HSF) обнаружены 47 генов, включая 7 CsHSP90, 18 CsHSP70 и 22 CsHSP, экспрессия которых повышает устойчивость к окислительному стрессу (Ј. Chen с соавт., 2018). В АБК-опосредованном ответе на засуху показана важная роль транскрипционных факторов семейства bZIP. B семействе Dof у чая описаны 29 транскрипционных факторов, показана их повышенная экспрессия у устойчивых сортов в условиях стресса. Для семейства SBP у чайного растения показана повышенная экспрессия генов CSSBP и предполагается их участие в сигнальных путях с участием АБК, гибберелловой кислоты, и метилжасмоната (P. Wang с соавт., 2018). Гены семейства липоксигеназ CsLOX1, CsLOX6 и CsLOX7 также важны при формировании ответа на засуху (J. Zhu c соавт., 2018). МикроРНК у чая регулируют экспрессию транскрипционных факторов на этапе трансляции. (Y. Guo с соавт., 2017). Несмотря на значительный прогресс в функциональной геномике растений, необходимы дальнейшие исследования для выяснения роли различных генов в регуляторных сетях и ответе на засуху.

Ключевые слова: Camellia sinensis (L.) Kuntze, чай, засуха, фитогормоны, осмолиты, антиоксидантная система, транскрипционные факторы.

Чай Camellia sinensis (L.) Kuntze - важнейшая промышленная культура, которую возделывают более чем в 50 странах мира, в том числе во

* Исследования проводятся при поддержке РНФ (проект № 18-76-10001). 458 
влажно-субтропической зоне России. Это многолетнее растение, произрастающее на одном месте до 70 лет и более, в летний период периодически сталкивается с продолжительной засухой (1-2 мес), приводящей к окислительному стрессу и формированию минеральной недостаточности. По данным разных авторов, эти абиотические факторы становятся одной из основных причин снижения урожайности чайных плантаций (в среднем на 15-45 \%) (1-3) и даже частичной гибели растений (до $19 \%$ ) (4). Прогнозируемые глобальные изменения климата в направлении аридизации (5) еще сильнее усугубят существующие проблемы возделывания чая и актуализируют задачи по повышению его выносливости к экстремальным экологическим условиям (6-9). В этой связи изучаются физиолого-биохимические и молекулярные механизмы устойчивости растений чая к засухе, эффективность применения различных экзогенных индукторов, ведется селекционный поиск более засухоустойчивых сортов (10). За годы исследований за рубежом накоплен значительный экспериментальный материал, касающийся физиолого-биохимических и молекулярных механизмов устойчивости чая и других культур к засухе (11-14), который может служить научной базой для развития селекционных исследований в России.

Целью настоящего обзора стало обобщение международного опыта фенотипирования и генотипирования чайного растения по признаку устойчивости к стресс-фактору для составления целостной картины реакции растения на осмотический стресс и понимания воспроизводимости механизмов ответа в разных климатических зонах.

$\mathrm{K}$ наиболее эффективным стратегиям адаптации растений, в том числе чая, к засухе относятся так называемые механизмы избегания воздействия стресса посредством сокращения жизненного цикла, периода вегетации и цветения, продолжительности плодоношения, которые направлены на снижение потери воды организмом $(15,16)$. Важнейшими морфологическими признаками адаптации растений служат характеристики корневой системы (биомасса, длина, глубина и плотность корней) (17-19), соотношение биомассы корни/побеги, число и размер листьев, площадь и характер листовой поверхности, соотношение массы листа к поверхности, структура фотосинтетического аппарата, строение и форма хлоропластов (20-24). Главные физиологические механизмы избегания снижение потери воды посредством устьичного контроля транспирации (25-27), уменьшение числа и размера устьиц (28), повышение вязкости цитоплазмы, поддержание осмотического потенциала клетки. В основе всех этих процессов лежат каскады биохимических реакций с участием трех групп метаболитов - фитогормонов, осмолитов и антиоксидантных компонентов.

Ф и т о го р м оны. Согласно современным исследованиям, среди фитогормонов важная роль в ответе на засуху принадлежит абсцизовой (АБК), салициловой и жасмоновой кислотам, а также этилену. При сравнительном изучении двух контрастных по устойчивости сортов чая было установлено увеличение содержания абсцизовой и салициловой кислот через 4 сут с момента наступления засухи (25). Другие фитогормоны, такие как индолилуксусная кислота (ИУК) и цитокинины, участвовали в восстановлении растений после засухи. Для чайного растения достаточно полно изучен АБК-зависимый путь ответа на засуху, хотя некоторые звенья еще не выявлены. АБК-зависимый сигналинг в первую очередь воздействует на конститутивно экспрессирующиеся транскрипционные факторы, которые затем индуцируют прямые эффекторные гены стрессоустойчивости (29). Ключевое регуляторное звено в биосинтезе АБК как в 
корнях, так и в листьях, вероятно, катализируется 9-цис-эпоксикаратиноиддезоксигеназой - ферментом, превращающим предшественник эпоксикаротиноид в ксантоксин в пластидах. АБК инициирует образование активных форм кислорода, которые по цепочке активируют супероксиддисмутазу (СОД) - первую линию обороны против свободных радикалов (12, 25). Возрастающая активность СОД приводит к увеличению количества $\mathrm{H}_{2} \mathrm{O}_{2}$, активации $\mathrm{Ca}^{2+}$ каналов и кальций-зависимых протеинкиназ, регулирующих закрытие устьиц (26, 30-32). При восстановлении после засухи уменьшается количество АБК, в результате чего предположительно снижается концентрация кальция в цитозоле, уменьшается приток калия и анионов в замыкающие клетки устьиц и, как следствие, происходит открытие устьиц $(26,33-35)$.

Под действием засухи повышается экспрессия гена синтеза жасмоновой кислоты, которая превращается в более активное соединение (-)-жасмоноил-L-изолейцин (JA-Ile) (26). Также активируются гены, кодирующие основные компоненты передачи сигналов этилена. После наступления стресса повышается экспрессия гена 1-аминоциклопропан-1карбоновой кислоты (АСC), что указывает на накопление этилена, а в период восстановления после засухи она подавляется (26).

Салициловая кислота - фенольное соединение, участвующее в регуляции фотосинтеза, метаболизма азота, пролина, синтеза глицин-бетаина, антиоксидантной системы защиты и водного потенциала в условиях стресса (36). Главный регулятор метаболизма салициловой кислоты - ген NPR1, снижение экспрессии которого в условиях засухи приводило к ослаблению устойчивости чая к болезням (26).

Индолилуксусная кислота (ИУК) регулирует многие физиологические процессы. У чайного растения в ответ на засуху снижалась экспрессия генов, связанных с синтезом ИУК (26). Однако для поддержания активности физиологических процессов в этих условиях включались альтернативные пути синтеза ИУК - из индола через триптофан.

Сообщалось, что в период засухи у чайного растения повышалась экспрессия генов, кодирующих ферменты биосинтеза цитокининов (транси цис-зеатин и изопентиниладенин), а при восстановлении после стресса она снижалась. По-видимому, увеличение содержания цитокининов может частично смягчать негативное влияние стресса на фотосинтетическую активность и замедлять ускоренное старение листьев (36).

О с м ол и ты. Еще одной стратегией адаптации к засухе служит повышение синтеза осмолитов - растворенных в цитозоле веществ с низкой молекулярной массой, которые даже в высоких концентрациях не токсичны для растения (37-39). Осмолиты повышают вязкость цитоплазмы, поглощают активные формы кислорода и защищают макромолекулы от свободных радикалов, тем самым поддерживая целостность мембран и метаболическую активность тканей, что обеспечивает возобновление роста после улучшения водного режима (40-42). Эти вещества относятся к трем основным классам: аминокислотам (глутамин, пролин, глицин-бетаин, карнитин), сахарам (крахмал, ди- и моносахариды) и полиолам (маннитол, сорбитол) (43). Среди аминокислот особенно важен пролин (44), который синтезируется из глутамата (с участием фермента пирролин-5-карбоксилатсинтазы) или орнитина $(26,43)$. Накопление пролина сопровождается предотвращением денатурации белка, сохранением структуры и активности ферментов, а также защитой мембран от повреждения АФК при дефиците влаги и высокой солнечной активности. Также к наиболее изученным компонентам осмотической регуляции относится глицин-бетаин 
(45), который оказывает положительное влияние на стабильность ферментов и целостность мембран, действуя как осмопротектор, а также опосредованно участвует в трансдукционных сигналах (46). В исследовании, проведенном T.K. Maritim с соавт. (19) на 8 сортах чая при моделируемом вододефицитном стрессе, было показано накопление в листьях пролина и глицин-бетаина, более выраженное у засухоустойчивых сортов. На основании этого сделан вывод о возможности использования пролина в качества биохимического маркера при скрининге генетического материала на засухоустойчивость.

Показан также значительный вклад углеводов в устойчивость клеток при осмотическом стрессе $(25,26,47)$. Так, в условиях засухи у чая происходило расщепление крахмала до глюкозы, повышение синтеза маннита, трегалозы, сахарозы. Накопление активных форм кислорода (АФК) напрямую коррелировало с накоплением глюкозы, которая участвует в закрытии устьиц и повышает адаптивность растения, предотвращает распад хлорофилла и транспирацию воды при осмотическом стрессе. Кроме того, растворимые сахара играют двойную функцию, поскольку связаны как с анаболизмом, так и с катаболизмом АФК, таким как окислительный пентозофосфатный путь, выработка НАДФН (48-51). Физиологические и молекулярно-генетические исследования S.C. Liu c соавт. $(25,26)$ показали, что концентрация растворимых сахаров в чайном растении значительно увеличивалась по мере усиления засухи, а затем быстро снижалась после регидратации. Эти результаты позволили предположить, что фотоассимилированный углерод преимущественно использовался для синтеза осмолитов, а крахмал в основном разлагался до глюкозы.

Антиоксидантные компоненты. Системы антиоксидантной защиты включают как ферментный (СОД, каталазу, пероксидазу, аскорбат-пероксидазу, глутатион-редуктазу), так и неферментный (цистеин, редуцированный глутатион и аскорбиновую кислоту) компоненты $(27,37$, 52). Установлено, что кроме каталазы, различных пероксидаз и пероксидоксинов $(25,53,46)$, еще несколько ферментов вовлечены в процесс избавления от перекиси водорода и свободных радикалов: дегидроаскорбатредуктаза, монодегидроаскорбат-редуктаза, глутатион-редуктаза (31, 54). Как показали транскриптомные исследования S.C. Liu с соавт. (26), в условиях засухи у чайного растения экспрессия гена ключевого фермента цикла Кальвина - рибулозобифосфат карбоксилазы (RuBisCO) снижалась, что указывало на ингибирование фиксации углекислого газа. При этом синтез регуляторных ферментов гликолиза гексокиназы в условиях засухи не прекращался. Исследователи предположили, что растение чая сохраняет поставки АТФ посредством поддержания гликолитического метаболизма (26). Выявлена роль $\beta$-каротина в защите от окислительного стресса и поддержании фотохимических процессов $(55,56)$, которая предположительно заключается в прямом гашении триплетного хлорофилла, что препятствует образованию активных форм кислорода (37).

Другие сигнальные пути. Группа молекулярных мессенджеров, регулирующих работу генов ответа, очень многочисленна. Так, аквапорины - семейство основных мембранных (плазматических и вакуолярных) белков - регулируют пассивный обмен воды через мембраны (57). Дегидрины и белки теплового шока (шапероны) стабилизируют структуру других белков и макромолекул, что предотвращает их денатурацию в условиях стресса (58).

Протеинкиназы и протеинфосфатазы часто действуют совместно, фосфорилируя и дефосфорилируя свои мишени. Протеинкиназы у чайно- 
го растения играют положительную, а протеинфосфатазы - отрицательную регуляторную роль в ответе на засуху, обеспечивая поддержание гомеостаза и перенос сигналов в чайном растении. Согласно J. Wan с соавт. (59-62), все 29 кальций-зависимых протеинкиназ, обнаруженных у чая, содержат цис-элементы множественного стрессового ответа в промотерной зоне гена.

Генетические факторы. Среди всех механизмов транскрипционные факторы служат главными регуляторами ответа растения на абиотический стресс. У чая предполагается наличие 12 семейств транскрипционных факторов, вовлеченных в ответ на засуху: AP2/EREBP, bHLH, bZIP, HD-ZIP, HSF (HSP), MYB, NAC, WRKY, zinc-finger protein TFs, SCL, ARR, SPL (63-66).

Одно из крупнейших семейств транскрипционных факторов bHLH (basic helix-loop-helix) широко распространено у эукариот. Эти факторы обусловливают передачу сигналов и вторичный метаболизм брассиностероидов, жасмоновой кислоты, синтез антоцианов, модуляцию роста и развития растений, контроль развития зародыша, ветвления побегов, развития цветка и плодов. Кроме того, bHLH участвуют в передаче сигнала АБК и ответе растений на абиотические стрессы. У чая выявлено 39 генов $C s b H L H$, экспрессия которых усиливается в условиях засухи (67).

Семейство транскрипционных факторов NAC (NAM-ATAF1/2CUC) регулирует формирование апикальной меристемы, латеральных корней, вторичной клеточной стенки, старение листьев, развитие семян, биосинтез флавоноидов. Многие гены семейства NAC участвуют в ответе на стрессы и передаче гормональных сигналов. Анализ экспрессии этих генов у чайного растения при засухе позволил обнаружить гены-кандидаты $C s N A C 17$ и $C s N A C 30$, которые могут быть использованы в селекции чая на засухоустойчивость (68).

Группа транскрипционных факторов WRKY вовлечена в ответы на абиотический стресс. У чая был выявлен ген $C s W R K Y 2$, который участвует в механизмах защиты от воздействия засухи. Его наибольшая экспрессия наблюдалась в листьях, наименьшая - в цветках и побегах. Высокая степень экспрессии $C s W R K Y 2$ была отмечена в условиях засухи и холода. Показано, что белки WRKY могут действовать как активаторы или репрессоры АБК (69).

Одно из наиболее обширных семейств транскрипционных факторов растений - DREBs (dehydration-responsive element-binding proteins). $\mathrm{У}$ чая было выявлено $29 C S D R E B$ генов, показана их локализация в ядре клеток. Экспрессия этих генов усиливалась под влиянием различных абиотических стрессов, в том числе засухи. Гиперэкспрессия генов CsDREB повышала устойчивость к стрессам как через АБК-зависимый, так и через АБК-независимый путь. Анализ экспрессии генов $C s D R E B$ показал, что они могут действовать как связующее звено между разными цепочками реакций при ответе чая на стресс (70).

Семейство белков HD-Zip (homeodomain-leucine zipper) составляет важную группу транскрипционных факторов, которую подразделяют на четыре подгруппы (HD-Zip I, HD-Zip II, HD-Zip III и HD-Zip IV). У чая найдены 33 транскрипционных фактора, принадлежащие к этим подгруппам. Среди них наиболее вовлечены в ответ на засуху HD-Zip I и HD-Zip IV. Белки HD-Zip I в основном отвечают на внешние сигналы, такие как экстремальные температуры, засуха и другие абиотические стрессы, регулируя процессы роста и адаптации растений к факторам среды. Подгруппа HD-Zip IV вовлечена в формирование корней, дифференциацию клеток, 
образование трихом, накопление антоциана. Результаты анализа экспрессии генов $C s h d z$ чая подтвердили их участие в различных стрессовых ответах, в том числе на засуху (71).

Белки теплового шока HSPs (heat shock proteins) играют важную роль в росте и развитии растений и защищают клеточные структуры в условиях стрессов. У чая выявлены 47 генов CsHSP, включая 7 CsHSP9O, 18 CsHSP70 и 22 CssHSP, экспрессия которых повышает устойчивость к окислительному стрессу, защищая фотосистему II и поддерживая работу фотосинтетического аппарата (72).

Транскрипционные факторы семейства bZIP (basic region/leucine zipper) разделяются на 13 групп (A-L и S). Наиболее изученная группа A включает так называемые ABRE-связывающие факторы (ABFs), отвечающие за работу АБК. Эти и другие гены семейства bZIP вовлечены в ответ и механизмы реализации устойчивости растений чая при засухе, выполняют функцию положительных регуляторов устойчивости к окислительному стрессу, играют центральную роль в биохимических каскадах с участием глюкозы и АБК (73).

Семейство транскрипционных факторов Dof (DNA-binding with one finger) регулирует экспрессию генов, вовлеченных в созревание и прорастание семян, периодизм цветения, накопление вторичных метаболитов, а также в защитные процессы. У чая выявлено 29 транскрипционных факторов Dof и показано участие $C s D o f-22$ в биосинтезе АБК. У устойчивых сортов чая в условиях стресса наблюдалось усиление экспрессии генов CsDof (74).

SBP (SQUAMOSA promoter binding protein) кодируют транскрипционные факторы, участвуют в спорогенезе, развитии побега и листа, цветении, оплодотворении, созревании плодов, передаче гормональных сигналов и ответах на абиотические и биотические стрессы у многих видов растений. Гиперэкспрессия этих генов наблюдалась в ответ на повышение содержание жасмоновой кислоты и приводила к повышению содержания супероксиддисмутазы и пероксидазы. У чайного растения показана повышенная экспрессия генов $C S S B P$ в почках и листьях; эти реакции могут быть связаны с сигнальными путями с участием АБК, гибберелловой кислоты и метилжасмоната (75).

Оксилипины - окисленные производные жирных кислот, включая жасмоновую кислоту, гидрокси-, оксо- или кето-жирные кислоты, летучие альдегиды, служат важными сигнальными молекулами у высших растений. Липоксигеназы (LOXs) составляют семейство железосодержащих ферментов, которые катализируют окисление полиненасышенных жирных кислот, что инициирует биосинтез оксилипинов. У чайного растения гены семейства липоксигеназ CsLOX1, CsLOX6 и CsLOX7 вовлечены в ответ на стрессы (холод, засуха, биотический стресс) по АБК-независимому пути (76).

МикроРНК регулируют экспрессию транскрипционных факторов на этапе трансляции. У чая выявлены 62 микроРНК, которые участвуют в ответе на засуху через регуляцию транскрипции и подавление трансляции. Установлено, что экспрессия микроРНК варьирует в зависимости от силы стресс-фактора и проявляется в виде морфологических, физиологических и биохимических изменений (77).

Таким образом, для растений чая установлены и описаны многие биохимические и генетические сигналы, которые в ответ на осмотический стресс активируют генетические матрицы, что приводит к физиологическим и метаболическим изменениям, обеспечивающим устойчивость 
растений. В этот процесс вовлечено множество генов, участвующих в метаболизме и сигналинге фитогормонов, метаболизме осмолитов, регуляции антиоксидантной активности, регуляции функций устьичного аппарата. Однако роль всех генетических факторов в ответе на засуху еще требует дополнительного изучения для полного понимания их места в каскадах биохимических реакций. Поэтому, несмотря на существенный прогресс в функциональной геномике растений, в том числе чая, необходимы дальнейшие исследования для выявления места различных генов в регуляторных сетях и ответе на засуху.

\title{
ФГБНУ Всероссийский НИИ иветоводства Поступила в редакцию и субтропических культур,
}

354002 Россия, г. Сочи, ул. Яна Фабрициуса, 2/28,

e-mail: samarinalidia@gmail.com,ryndin@vniisubtrop.ru,

malukovals@mail.ru凶, m.v.gvasaliya@mail.ru,malyarovskaya@yandex.ru

\section{PHYSIOLOGICAL MECHANISMS AND GENETIC FACTORS OF THE TEA PLANT Camellia sinensis (L.) Kuntze RESPONSE TO DROUGHT (review)}

\author{
L.S. Samarina, A.V. Ryndin, L.S. Malyukova, M.V. Gvasaliya, V.I. Malyarovskaya
}

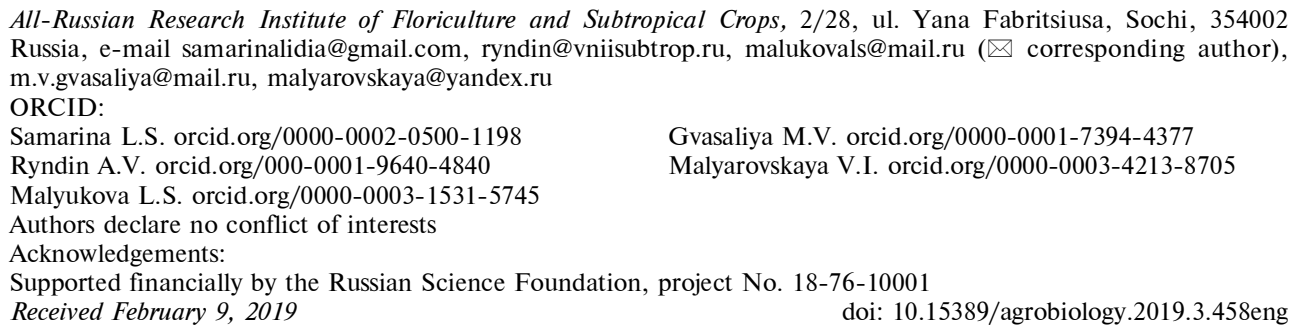

Abstract

The main constraint in the tea plants growth in the world is drought, which reduces the productivity of plantations by 15-45 \% (R.M. Bhagat et al., 2010; R.D. Baruah et al., 2012). In this regard, physiological (M. Mukhopadhyay et al., 2014; T.K. Maritim et al., 2015) and molecular mechanisms (W.D. Wang et al, 2016; Y. Guo et al., 2017) drought tolerance of tea plants are a matter of great interest. The purpose of this review is to summarize the international experience of phenotyping and genotyping of tea drought response to create a comprehensive picture of the plant response to osmotic stress and to understand the reproducibility of response mechanisms in different climatic regions. During drought stress the main signaling role is played by abscisic, jasmonic and salicylic acids, as well as ethylene (S.C. Liu et al., 2016), the metabolic pathway of which includes cascades of physiological changes and involves response genes (T. Umezawa et al., 2010). It was reported that tea plants had increased expression of genes encoding cytokinin biosynthesis enzymes (trans-zeatin and cis-zeatin and isopentyniladine) under drought, and during recovery its expression decreased. It is assumed that an increase in cytokinin content may partially mitigate the negative effect of stress on photosynthetic apparatus and slow down leaf senescence induced by stress. An important adaptive response of tea plant to drought is an increase in the concentration of proline, glycine-betaine, mannitol and other osmolytes which neutralize reactive oxygen species, protect macromolecules from damage by free radicals, and maintain the osmotic potential of the cell (W.D. Wang et al., 2016). Under the drought in tea plant starch decomposes to glucose, and mannitol, trehalose, and sucrose contents increase. The accumulation of reactive oxygen species (ROS) directly correlates with the accumulation of glucose, to prevent the negative effects of stress. In addition, it has been shown that many genes involved in the metabolism and signaling of phytohormones, osmolytes, antioxidants and carbohydrates are also involved in tolerance to osmotic stress (S. Gupta et al., 2013; Y. Guo et al., 2017). Several families of transcription factors play a crucial role in the regulation of tea response to drought in tea. In particular, 39 CsbHLH genes were identified with increased expression in drought conditions (X. Cui et al., 2018). From the NAC family, the CsNAC17 and CsNAC30 genes have been identified that can be used in the breeding for 
drought tolerance of tea (Y.-X. Wang et al., 2016). From the WRKY family, the CsWRKY2 gene has been identified which is involved in the mechanisms of protection from drought and can act as an activator or repressor of abscisic acid (ABA). From the DREB gene family, 29 CsDREB have been identified, which increase drought tolerance of tea through ABA-dependent and ABA-independent pathways and can act as a link between different biochemical networks in response to drought (M. Wang et al., 2017). From the HD-Zip family, $C s h d z$ genes have been identified which are divided into 4 groups according to their functions, of which HD-Zip I and HD-Zip IV play the major role in drought response in tea (W. Shen et al., 2018). Of the HSP (HSF) family, 47 transcription factors were identified in tea, including 7 CsHSP90, 18 CsHSP70, and 22 CsHSP genes the expression of which increases resistance to oxidative stress, protection of photosystem II and stabilizes photosynthesis during drought (J. Chen et al., 2018). The transcription factors of the bZIP family also play the important role in ABA-mediated drought response. From the Dof family, 29 transcription factors were revealed in tea plants and their increased expression was shown in the resistant cultivars under drought. The important role of CsDof-22 in ABA biosynthesis has been revealed (H. Li et al., 2016). An increased expression of the SBP family CSSBP genes in tea plants led to assumption of its participation in signaling pathways involving ABA, gibberellic acid, and methyl jasmonate ( $\mathrm{P}$. Wang et al., 2018). The genes of the CsLOX1, CsLOX6 and CsLOX7 family of lipoxygenases in tea can also play an important role in drought response (J. Zhu et al., 2018). In addition, miRNA play an important role in gene regulation at transcription and translation level in tea plants (Y. Guo et al., 2017). Despite the great progress in the functional genomics of tea plant further research is needed to identify the location of various genes in regulatory networks and their impact in drought tolerance.

Keywords: tea plant, Camellia sinensis, drought, phytohormones, osmolytes, antioxidant system, transcription factors.

\section{REFEREN CES}

1. Bhagat R.M., Baruah R.D., Safigue S. Climate and tea [Camellia sinensis (L.) O. Kuntze] production with special reference to north eastern India: a review. Journal of Environmental Research and Development, 2010, 4(4): 1017-1028.

2. Baruah R.D., Bhagat R.M. Climate trends of Northeastern India: a longterm pragmatic analysis for tea production. Two and a Bud, 2012, 59(2): 46-49.

3. Malyukova L.S. Plodovodstvo i yagodovodstvo Rossii, 2014, 38(1): 255-261 (in Russ.).

4. Cheruiyot E.K., Mumera L.M., Ng'etich W.K., Hassanali A., Wachira F.N. High fertilizer rates increase susceptibility of tea to water stress. Journal of Plant Nutrition, 2009, 33(1): 115-129 (doi: 10.1080/01904160903392659).

5. Reynolds M.P., Ortiz R. Adapting crops to climate change: a summary. In: Climate change and crop production. M.P. Reynolds (ed.). CAB International, 2010: 1-8 (doi: 10.1079/9781845936334.0001).

6. Sinclair T.R. Challenges in breeding for yield increase for drought. Trends in Plant Science, 2011, 16(6): 289-293 (doi: 10.1016/j.tplants.2011.02.008).

7. Ashraf M. Inducing drought tolerance in plants: recent advances. Biotechnology Advances, 2010, 28(1): 169-183 (doi: 10.1016/j.biotechadv.2009.11.005).

8. Varshney R.K., Bansal K.C., Aggarwal P.K., Datta S.K., Craufurd P.Q. Agricultural biotechnology for crop improvement in a variable climate: hope or hype? Trends in Plant Science, 2011; 16(7): 363-371 (doi: 10.1016/j.tplants.2011.03.004).

9. Tsonev S., Todorovska E., Avramova V., Kolev S., Abu-Mhadi N., Christov N.K. Genomics assisted improvement of drought tolerance in maize: QTL approaches. Biotechnology \& Biotechnological Equipment, 2009, 23(4): 1410-1413 (doi: 10.2478/V10133-009-0004-8).

10. Mukhopadhyay M., Mondal T.K. The physio-chemical responses of Camellia plants to abiotic stresses. J. Plant Sci. Res., 2014, 1(1): 1-12.

11. Bernier J., Atlin G.N., Serraj R., Kumar A., Spaner D. Breeding upland rice for drought resistance. Journal of the Science of Food and Agriculture, 2008, 88(6): 927-939 (doi: 10.1002/jsfa.3153).

12. Fleury D., Jefferies S., Kuchel H., Langridge P. Genetic and genomic tools to improve drought tolerance in wheat. Journal of Experimental Botany, 2010, 61(12): 3211-3222 (doi: $10.1093 / \mathrm{jxb} / \mathrm{erq} 152)$.

13. Manavalan L.P., Guttikonda S.K., Tran L.S., Nguyen H.T. Physiological and molecular approaches to improve drought resistance in soybean. Plant and Cell Physiology, 2009, 50(7): 1260-1276 (doi: 10.1093/pcp/pcp082).

14. Yadav R.S., Sehgal D., Vadez V. Using genetic mapping and genomics approaches in understanding and improving drought tolerance in pearl millet. Journal of Experimental Botany, 2011, 62(2): 397-408 (doi: 10.1093/jxb/erq265).

15. Araus J.L., Slafer G.A., Reynolds M.P., Royo C. Plant breeding and water relations in $\mathrm{C}_{3}$ cereals: what should we breed for? Annals of Botany, 2002, 89 (7): 925-940 (doi: 10.1093/aob/mcf049).

16. Pchikhachev E.K., Korzun B.V. Subtropicheskie kul'tury, 2010, 1(4): 219-220 (in Russ.).

17. Tuov M.T. Nauchnye osnovy povysheniya kachestva i produktivnosti chainykh plantatsii Rossii. 
Doktorskaya dissertatsiya [Scientific basis for improving quality and productivity of tea plantations in Russia. DSc Thesis]. Sochi, 1997 (in Russ.).

18. Das A., Das S., Mondal T.K. Identification of differentially expressed gene profiles in young roots of tea (Camellia sinensis (L.) O. Kuntze) subjected to drought stress using suppression subtractive hybridization. Plant Mol. Biol. Rep., 2012, 30(5): 1088-1101 (doi: 10.1007/s11105-0120422-x).

19. Maritim T.K., Kamunya S.M., Mireji P., Mwendia C.M., Muoki R.C., Cheruiyot E.K., Wachira F.N. Physiological and biochemical response of tea (Camellia sinensis (L.) O. Kuntze) to water-deficit stress. The Journal of Horticultural Science and Biotechnology, 2015, 90(4): 395-400 (doi: 10.1080/14620316.2015.11513200).

20. Jaleel C.A., Manivannan P., Wahid A., Farooq M., Somasundaram R., Panneerselvam R. Drought stress in plants: a review on morphological characteristics and pigments composition. Int. J. Agric. Biol., 2009, 11(1): 100-105.

21. Waheed A., Hamid F.S., Shan A.H., Ahmad H., Khalid A., Abbasi F.M., Ahmad N., Aslam S., Sarwar S. Response of different tea (Camellia sinensis L.) clones against drought stress. J. Mater. Environ. Sci., 2012, 3(2): 395-410.

22. Gvasaliya M.V. Spontannye $i$ indutsirovannye sorta i formy chaya (Samellia sinensis (L.) Kuntze) vo vlazhnykh subtropikakh Rossii $i$ Abkhazii, perspektivy ikh razmnozheniya $i$ sokhraneniya $v$ kul'ture in vitro. Kandidatskaya dissertatsiya [Spontaneous and induced varieties and forms of tea (Camellia sinensis (L.) Kuntze) in the humid subtropics of Russia and Abkhazia, the prospects for their reproduction and preservation in culture in vitro. PhD Thesis]. Krasnodar, 2015 (in Russ.).

23. Nyabundi K.W., Owuor P.O., Netondo G.W., Bore J.K. Genotype and environment interactions of yields and yield components of tea (Camellia sinensis) cultivars in Kenya. American Journal of Plant Sciences, 2016, 7(6): 855-869 (doi: 10.4236/ajps.2016.76081).

24. Vavilova L.V., Korzun B.V. Novye tekhnologii, 2016, 4: 114-120 (in Russ.).

25. Liu S.C., Yao M.Z., Ma C.L., Jin J.Q., Ma J.Q., Li C.F. Physiological changes and differential gene expression of tea plant under dehydration and rehydration conditions. Scientia Horticulturae, 2015, 184(5): 129-141 (doi: 10.1016/j.scienta.2014.12.036).

26. Liu S.C., Jin J.Q., Ma J.Q., Yao M.Z., Ma C.L., Li C.F., Ding Z.T., Chen L. Transcriptomic analysis of tea plant responding to drought stress and recovery. PLoS ONE, 2016, 11(1): e0147306 (doi: 10.1371/journal.pone.0147306).

27. Li X., Liu F. Drought stress memory and drought stress tolerance in plants: biochemical and molecular basis. In: Drought stress tolerance in plants. M. Hossain, S. Wani, S. Bhattacharjee, D. Burritt, L.S. Tran (eds.). Springer, Cham, 2016, Vol. 1: 17-44 (doi: 10.1007/978-3-31928899-4).

28. Daszkowska-Golec A.D., Szarejko I. Open or close the gate-stomata action under the control of phytohormones in drought stress conditions. Front. Plant Sci., 2013, 4: 138 (doi: 10.3389/fpls.2013.00138).

29. Umezawa T., Nakashima K., Miyakawa T., Kuromori T., Tanokura M., Shinozaki K., Yamaguchi-Shinozaki K. Molecular basis of the core regulatory network in ABA responses: sensing, signaling and transport. Plant Cell Physiol., 2010, 51(11): 1821-1839 (doi: 10.1093/pcp/pcq156).

30. Miller G., Schlauch K., Tam R., Cortes D., Torres M.A., Shulaev V., Jeffery L. Dang, Mittler R. The plant NADPH oxidase RBOHD mediates rapid systemic signaling in response to diverse stimuli. Science Signaling, 2009, 2(84): 1-10 (doi: 10.1126/scisignal.2000448).

31. Upadhyaya H., Dutta B.K., Sahoo L., Panda S.K. Comparative effect of Ca, K, Mn and B on post-drought stress recovery in tea [Camellia sinensis (L.) O. Kuntze]. American Journal of Plant Sciences, 2012, 3(4): 443-460 (doi: 10.4236/ajps.2012.34054).

32. Meyer S., Mumm P., Imes D., Endler A., Weder B., Al-Rasheid K.A.S., Geiger D., Marten I., Martinoia E., Hedrich R. AtALMT12 represents an R-type anion channel required for stomatal movement in Arabidopsis guard cells. The Plant Journal, 2010, 63(6): 1054-1062 (doi: 10.1111/j.1365-313X.2010.04302.x).

33. Upadhyaya H., Panda S.K., Dutta B.K. $\mathrm{CaCl} 2$ improves post-drought recovery potential in Camellia sinensis (L) O. Kuntze. Plant Cell Rep., 2011, 30(4): 495-503 (doi: 10.1007/s00299010-0958-x).

34. Gao X.Y., Yang G.P., Xu Z.Q. Xu F.C. Effect of calcium on antioxidant enzymes of lipid peroxidation of soy-bean leaves under water stress. J. South China Agric. Univ., 1999, 2: 58-62.

35. Bowler C., Fluhr B. The role of calcium and activated oxygen as signals for controlling crosstolerance. Trends Plant Sci., 2000, 5(6): 241-243 (doi: 10.1016/S1360-1385(00)01628-9).

36. Miura K., Tada Y. Regulation of water, salinity, and cold stress responses by salicylic acid. Front. Plant Sci., 2014, 5: 4 (doi: 10.3389/fpls.2014.00004).

37. Defez R., Andreozzi A., Dickinson M., Charlton A., Tadini L., Pesaresi P., Bianco C. Improved drought stress response in alfalfa plants nodulated by an IAA over-producing Rhizobium strain. Front Microbiol., 2017, 14(8): 2466 (doi: 10.3389/fmicb.2017.02466).

38. Farooq M., Wahid A., Kobayashi N., Fujita D., Basra S.M.A. Plant drought stress: effects, mechanisms and management. Agron. Sustain. Dev., 2009, 29(1): 185-212 (doi: 10.1051/agro:2008021). 
39. Damayanthi M.M.N., Mohotti A.J., Nissanka S.P. Comparison of tolerant ability of nature field grown tea (Camellia sinensis L.) cultivars exposed to a drought stress in Passara Area. Tropical Agricultural Research, 2010, 22(1): 66-75 (doi: 10.4038/tar.v22i1.2671).

40. Mukhopadhyay M., Ghosh P.D., Mondal T.K. Effect of boron deficiency on photosynthesis and antioxidant responses of young tea (Camellia sinensis (L.) O. Kuntze) plantlets. Russ. J. Plant Physiol., 2013, 60(5): 633-639 (doi: 10.1134/S1021443713030096).

41. Pritula Z.V., Malyukova L.S. Problemy agrokhimii i ekologii, 2017, 3: 31-34 (in Russ.).

42. Tholakalabavi A., Zwiazek, J.J, Thorpe, T.A. Effect of mannitol and glucose-induced osmotic stress on growth, water relations, and solute composition of cell suspension cultures of poplar (Populus deltoids var. Occidentalis) in relation to anthocyanin accumulation. In Vitro Cell Dev. Biol. - Plant, 1994, 30(3): 164-170 (doi: 10.1007/BF02632208).

43. Serraj R., Sinclair T.R. Osmolyte accumulation: can it really help increase crop yield under drought conditions? Plant, Cell Environ., 2002, 25(2): 333-341 (doi: 10.1046/j.13653040.2002.00754.x).

44. Guo Y., Zhao S., Zhu C.H., Chang X., Yue C.H., Wang Z.H., Lin Y., Lai Z.H. Identification of drought-responsive miRNAs and physiological characterization of tea plant (Camellia sinensis L.) under drought stress. BMC Plant Biol., 2017, 17(1): 211 (doi: 10.1186/s12870-017-1172-6).

45. Szabados L., Savoure A. Proline: a multifunctional amino acid. Trends Plant Sci., 2010, 15(2): 89-97 (doi: 10.1016/j.tplants.2009.11.009).

46. Farooq M., Basra S.M.A., Wahid A., Cheema Z.A., Cheema M.A., Khaliq A. Physiological role of exogenously applied glycinebetaine in improving drought tolerance of fine grain aromatic rice (Oryza sativa L.). J. Agron. Crop Sci., 2008, 194(5): 325-333 (doi: 10.1111/j.1439037X.2008.00323.x).

47. Upadhyaya H., Panda S.K. Abiotic stress responses in tea [Camellia sinensis (L.) O. Kuntze]: an overview. Reviews in Agricultural Science, 2013, 1: 1-10 (doi: 10.7831/ras.1.1).

48. Ciereszko I. Sucrose metabolism in plant tissues under stress conditions: key enzymes, localization and function In: Compartmentation of responses to stresses in higher plants, true or false. W. Maksymiec (ed.). Transworld Research Network, Trivandrum, 2009: 193-218 (ISBN: 978 81-7895-422-6).

49. ElSayed A.I., Rafudeen M.S., Golldack D. Physiological aspects of raffinose family oligosaccharides in plants: protection against abiotic stress. Plant Biology, 2014, 16(1): 1-8 (doi: 10.1111/plb.12053).

50. Sami F., Yusuf M., Faizan M., Faraz A., Hayat S. Role of sugars under abiotic stress. Plant Physiology and Biochemistry, 2016, 109: 54-61 (doi: 10.1016/j.plaphy.2016.09.005).

51. Thalmann M., Santelia D. Starch as a determinant of plant fitness under abiotic stress. New Phytologist, 2017, 214(3): 943-951 (doi: 10.1111/nph.14491).

52. Kamanga R.M., Mbega E., Ndakidemi P. Drought tolerance mechanisms in plants: physiological responses associated with water deficit stress in Solanum lycopersicum Adv. Crop. Sci. Tech., 2018, 6(3): 362 (doi: 10.4172/2329-8863.1000362).

53. Das A., Mukhopadhyay M., Sarkar B., Saha D., Mondal T.K. Influence of drought stress on cellular ultrastructure and antioxidant system in tea cultivars with different drought sensitivities. J. Environ. Biol., 2015, 36(4): 875-882.

54. Belous O.G. Aktivnost' katalazy v list'yakh chaya $v$ zone vlazhnykh subtropikov Rossii. LAP LAMBERT Academic Publishing, Saarbruchen, 2012.

55. Pedranzani H., Vigliocco A. Evaluation of jasmonic acid and salicylic acid levels in abiotic stress tolerance: Past and present. In: Mechanisms behind phytohormonal signalling and crop abiotic stress tolerance. Chapter 15. V.P. Singh, S. Singh, S.M. Prasad (eds.). Nova Science Publishers, 2017: 1-60.

56. Manivannan P., Jaleel C.A., Kishorekumar A., Sankar B., Somasundaram R., Sridharan R., Panneerselvam R. Drought stress induced changes in the biochemical parameters and photosynthetic pigments of cotton (Gossypium hirsutum L.). Indian J. Appl. Pure Biol., 2007, 22: 369-372.

57. Pritula Z.V., Malyukova L.S., Velikii A.V. Plodovodstvo i yagodovodstvo Rossii, 2017, 51: 299307 (in Russ.).

58. Tyerman S.D., Niemietz C.M., Bramley H. Plant aquaporins: multifunctional water and solute channels with expanding roles. Plant, Cell \& Environment, 2002, 25(2): 173-194 (doi: 10.1046/j.0016-8025.2001.00791.x).

59. Wahid A., Gelani S., Ashraf M., Foolad M.R. Heat tolerance in plants: an overview. Environmental and Experimental Botany, 2007, 61(3): 199-223 (doi: 10.1016/j.envexpbot.2007.05.011).

60. Spalding E.P., Harper J.F. The ins and outs of cellular $\mathrm{Ca}^{2+}$ transport. Current Opinion in Plant Biology, 2011, 14(6): 715-720 (doi: 10.1016/j.pbi.2011.08.001).

61. Saruhashi M., Ghosh T.K., Arai K., Ishizaki Y., Hagiwara K., Komatsu K., Shiwa Y., Izumikawa T., Yoshikawa H., Umezawa T., Sakata Y., Takezawa D. Plant Raf-like kinase integrates abscisic acid and hyperosmotic stress signaling upstream of SNF1-related protein kinase 2. Proceedings of the National Academy of Sciences, 2015, 112(46): E6388-6396 (doi: 10.1073/pnas. 1511238112).

62. Wan X., O’Quinn R.P., Pierce H.L., Joglekar A.P., Gall W.E., DeLuca J.G., Carroll C.W., 
Liu S.-T., Yen T. J., McEwen B.F., Stukenberg T., Desai A., Salmon E.D. Protein architecture of the human kinetochore microtubule attachment site. Cell, 2009, 137(4): 672-684 (doi: 10.1016/j.cell.2009.03.035).

63. Kim T.H., Böhmer M., Hu H.H., Nishimura N., Schroeder J.I. Guard cell signal transduction network: advances in understanding abscisic acid, $\mathrm{CO}_{2}$, and $\mathrm{Ca}^{2+}$ signaling. Annual Review of Plant Biology, 2010, 61: 561-591 (doi: 10.1146/annurev-arplant-042809-112226).

64. Gupta S., Bharalee R., Bhorali P., Das S.K., Bhagawati P., Bandyopadhyay T., B. Gohain, Agarwal N., Ahmed P., Borchetia S., Kalita M.C., Handique A.K., Das S. Molecular analysis of drought tolerance in tea by cDNA-AFLP based transcript profiling. Mol. Biotechnol., 2013, 53(3): 237-248 (doi: 10.1007/s12033-012-9517-8).

65. Gelmesa D., Dechassa N., Mohammed D., Gebre E., Monneveux P., Bündig C., Winkelmann T. In vitro screening of potato genotypes for osmotic stress tolerance. Open Agriculture, 2017, 2(1): 308-316 (doi: 10.1515/opag-2017-0035).

66. Wang W.D., Xin H.H., Wang M.L., Ma Q.P., Wang L., Kaleri N.A., Wang Y.H., Li X.H. Transcriptomic analysis reveals the molecular mechanisms of drought-stress-induced decreases in $\mathrm{Ca}$ mellia sinensis leaf quality. Front Plant Sci., 2016, 7(795): 385-412 (doi: 10.3389/fpls.2016.00385).

67. Cui X., Wang Y.-X., Liu Z.-W., Wang W.-L., Li H., Zhuang J. Transcriptome-wide identification and expression profile analysisof the bHLH family genes in Camellia sinensis. Functional \& Integrative Genomics, 2018, 18(5): 489-503 (doi: 10.1007/s10142-018-0608-x).

68. Wang Y.-X., Liu Z.-W., Wu Z.-J., Li H., Zhuang J. Transcriptome-wide identification and expression analysis of the NAC gene family in tea plant [Camellia sinensis (L.) O. Kuntze]. PLoS ONE, 2016, 11(11): e0166727 (doi: 10.1371/journal.pone.0166727).

69. Wang Y., Shu Z., Wang W., Jiang X., Li D., Pan J., Li X. CsWRKY2, a novel WRKY gene from Camellia sinensis, is involved in cold and drought stress responses. Biologia Plantarum, 2016, 60(3): 443-451 (doi: 10.1007/s10535-016-0618-2).

70. Wang M., Zhuang J., Zou Z., Li Q., Xin H., Li X. Overexpression of a Camellia sinensis DREB transcription factor gene (CsDREB) increases salt and drought tolerance in transgenic Arabidopsis thaliana. J. Plant Biol., 2017, 60: 452-461 (doi: 10.1007/s12374-016-0547-9).

71. Shen W., Li H., Teng R., Wang Y., Wang W., Zhuang J. Genomic and transcriptomic analyses of HD-Zip family transcription factors and their responses to abiotic stress in tea plant (Camellia sinensis). Genomics, 2018 (In Press, Corrected Proof) (doi: 10.1016/j.ygeno.2018.07.009).

72. Chen J., Gao T., Wan S., Zhang Y., Yang J., Yu Y., Wang W. Genome-wide identification, classification and expression analysis of the HSP gene superfamily in tea plant (Camellia sinensis). Int. J. Mol. Sci., 2018, 19(9): 2633 (doi: 10.3390/ijms19092633).

73. Wang L., Cao H., Qian W., Yao L., Hao X., Li N., Yang Y., Wang X. Identification of a novel bZIP transcription factor in Camellia sinensis as a negative regulator of freezing tolerance in transgenic arabidopsis. Annals of Botany, 2017, 119(7): 1195-1209 (doi: 10.1093/aob/mcx011).

74. Li H., Huang W., Liu Z.-W., Wang Y.-X., Zhuang J. Transcriptome-based analysis of Dof family transcription factors and their responses to abiotic stress in tea plant (Camellia sinensis). Int J Genomics, 2016: 5614142 (doi: 10.1155/2016/5614142).

75. Wang P., Chen D., Zheng Y., Jin S., Yang J., Ye N. Identification and expression analyses of SBP-box genes reveal their involvement in abiotic stress and hormone response in tea plant (Camellia sinensis). Int. J. Mol. Sci., 2018, 19(11): 3404 (doi: 10.3390/ijms19113404).

76. Zhu J., Wang X., Guo L., Xu Q., Zhao S., Li F., Yan X., Liu S., Wei C. Characterization and alternative splicing profiles of the lipoxygenase gene family in tea plant (Camellia sinensis). Plant and Cell Physiology, 2018, 59(9): 1765-1781 (doi: 10.1093/pcp/pcy091).

77. Guo Y., Zhao S., Zhu C., Chang X., Yue C., Wang Z., Lin Y., Lai Z. Identification of drought-responsive miRNAs and physiological characterization of tea plant (Camellia sinensis L.) under drought stress. BMC Plant Biology, 2017, 17: 211 (doi: 10.1186/s12870-017-1172-6). 